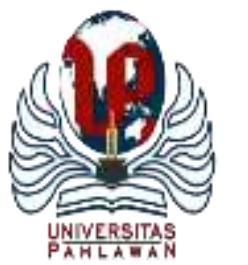

Edukatif : Jurnal Ilmu Pendidikan Volume 4 Nomor 1 Tahun 2022 Halm 508 - 515

EDUKATIF: JURNAL ILMU PENDIDIKAN

Research \& Learning in Education

https://edukatif.org/index.php/edukatif/index

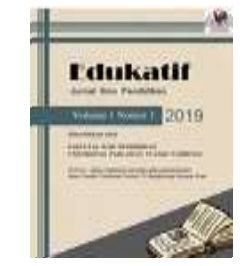

\title{
Penerapan Pembelajaran Daring Menggunakan Model Problem Based Learning pada Mata Kuliah Konsep Biologi
}

\author{
Ragil Dian Purnama Putri ${ }^{1 凶}$, Siti Fatonah ${ }^{2}$, Susilawati ${ }^{3}$ \\ UIN Sunan Kalijaga Yogyakarta ${ }^{1,2}$, UIN Sultan Syarif Kasim Riau ${ }^{3}$ \\ E-mail : 20204081007@student.uin-suka.ac.id ${ }^{1}$, $\underline{\text { siti.fatonah@uin-suka.ac.id }}^{2}, \underline{\text { susilawati@uin-suska.ac.id }}^{3}$
}

\begin{abstract}
Abstrak
Virus corona yang tak kunjung selesai mengakibatkan seluruh tatanan kehidupan berubah. Perguruan tinggi yang menjadi tempat mahasiswa mencari ilmu harus melakukan pembelajaran secara daring. Salah satu prodi di perguruan tinggi yaitu PGMI. PGMI telah mewajibkan mahasiswa untuk mempelajari berbagai ilmu termasuk Konsep Biologi. Dalam pembelajaran daring perlu adanya model pembelajaran yang tepat, salah satunya menggunakan model Problem Based Learning (PBL). Adapun tujuan dari penulisan artikel ini yaitu untuk mengetahui peningkatan pembelajaran daring menggunakan model PBL. Jenis penelitian yang digunakan yaitu pendekatan kualitatif dengan menggunakan rancangan penelitian tindakan. Adapun hasil yang didapatkan dalam penelitian ini yaitu pada siklus I pembelajaran daring menggunakan PBL belum efektif karena masih banyak mahasiswa yang tidak aktif dan salah dalam menjawab soal pertanyaan. Sedangkan, pada siklus II telah mengalami peningkatan, dimana mahasiswa terlihat aktif dalam mengikuti diskusi dan sudah banyak yang tidak salah lagi dalam mengerjakan soal pertanyaan. Dengan demikian, dapat disimpulkan bahwa penerapan pembelajaran daring dengan model PBL sangat efektif bagi mahasiswa PGMI UIN SUSKA Riau.
\end{abstract}

Kata Kunci: problem based learning, tindakan kelas, konsep biologi

\begin{abstract}
The unfinished corona virus has caused the whole order of life to change. Universities where students seek knowledge must conduct online learning. One of the study programs in higher education is PGMI. PGMI has required students to study various sciences including Biology Concepts. In online learning, it is necessary to have the right learning model, one of which is using themodel Problem Based Learning (PBL). The purpose of writing this article is to find out the improvement of online learning using the PBL model. The type of research used is a qualitative approach using an action research design. The results obtained in this study are that in the first cycle online learning using PBL has not been effective because there are still many students who are inactive and wrong in answering questions. Meanwhile, in cycle II there has been an increase, where students are seen to be active in participating in discussions and there are many who are not wrong in working on questions. Thus, it can be concluded that the application of online learning with the PBL model is very effective for students of PGMI UIN SUSKA Riau.
\end{abstract}

Keywords: problem based learning, classroom action, biological concepts

Copyright (c) 2022 Ragil Dian Purnama Putri, Siti Fatonah, Susilawati

$\triangle$ Corresponding author

Email : 20204081007@student.uin-suka.ac.id

DOI : https://doi.org/10.31004/edukatif.v4i1.1805

ISSN 2656-8063 (Media Cetak)

ISSN 2656-8071 (Media Online)

Edukatif : Jurnal Ilmu Pendidikan Vol 4 No 1 Tahun 2022 p-ISSN 2656-8063 e-ISSN 2656-8071 


\section{PENDAHULUAN}

Virus Covid-19 telah menyebar sekitar 2 tahun yang lalu sejak bulan Desember 2019. Pertama kali wabah Covid-19 muncul di negara Cina dan menyebar hampir di seluruh negara. Indonesia adalah salah satu negara yang terdampak pada virus Covid-19 ini. Saat ini terdapat 34 provinsi di Indonesia terjangkit virus Covid-19. Virus ini terus menyebar dan mengakibatkan kegiatan masyarakat mengalami perubahan. Perubahan yang dimaksud yaitu seperti tidak normalnya kehidupan seperti biasanya, (Putri and Prastowo 2021). Terjadinya pembatasan bersosial mengakibatkan masyarakat harus merubah pola kehidupan juga. Bahkan di pulau Jawa Bali kasus positif Covid-19 masih tinggi, (Setyadi \& Indriyan, 2021). Hal tersebut membuat pemerintah harus mengambil sikap yang tegas agar dapat memutus rantai Covid-19. Pemerintah bersama Kementrian Kesehatan memprogramkan vaksin gratis kepada masyarakat. Selain itu, protokol kesehatan harus tetap dijalankan seperti memakai masker, mencuci tangan, menjaga jarak, dan menghindari kerumunan.

Adapun kegiatan masyarakat yang terbatas, maka sekolah maupun perguruan tinggi yang menjadi tempat mencari ilmu pada pendidikan formal juga harus dilakukan secara daring. Hal ini sesuai dengan keputusan Kemendikbud dimana kegiatan belajar mengajar dilakukan secara daring atau Belajar Dari Rumah (BDR), (Kemendikbud n.d.). Pembelajaran daring memiliki ciri utama yaitu menggunakan gadget seperti handphone atau komputer melalui beberapa aplikasi online, (Safitri and Putri 2020). Selain itu, pembelajaran daring juga diartikan sebagai pembelajaran berbasis internet atau online yang menghubungkan antara siswa/mahasiswa dengan guru/dosen,(Sadikin and Hamidah 2020). Kegiatan pembelajaran daring ini masih dilakukan di zona merah dan daerah-daerah tertentu dengan tujuan memutus rantai Covid-19 pada lingkungan sekolah dan perguruan tinggi, (Putri and Suyadi, 2021). Padahal telah diketahui jika perguruan tinggi juga menentukan lulusan yang berkompeten pada bidangnya seperti bidang pendidikan yang nantinya akan menjadi seorang pendidik atau guru. Pendidikan guru salah satunya yaitu prodi Pendidikan Guru Madrasah Ibtidaiyah (PGMI) yang mempelajari Ilmu Pendidikan Alam (IPA) atau juga Ilmu Biologi, (Nurhayati, Rokhimawan, and Ragil Dian Purnama Putri 2021).

Berdasarkan studi pendahuluan pada prodi PGMI UIN SUSKA Riau bahwa pembelajaran daring pada mata kuliah Konsep Biologi masing memerlukan kegiatan praktik langsung. Dengan demikian, pembelajaran daring saat ini menjadi tantangan tersendiri bagi mahasiswa PGMI. Dalam menyikapi hal tersebut dilakukan penerapan model pembelajaran berbasis Problem Based Learning agar mahasiswa dapat melakukan perkuliahan dengan menyikapi permasalahan yang terjadi di sekitar lingkungannya. Model Problem Based Learning ini diterapkan pada mata kuliah Konsep Biologi sebagai bekal guru untuk mengajar di SD/MI nantinya. Adapun salah satu model pembelajaran yang dapat diterapkan dalam menunjang kemampuan berpikir kritis adalah Problem based learning (PBL). PBL adalah salah satu metode pembelajaran yang dapat memberikan nuansa berbeda karena membuat pembelajaran aktif dan siswa sebagai pusat belajar, (Brownell and Jameson 2004). Penelitian lain juga menunjukkan bahwa metode pembelajaran PBL ini dapat meningkatkan penguasaan konsep oleh siswa dibandingkan pembelajaran konvensional, (Demirel and Turan, 2010). Selain itu, pembelajaran PBL juga memberikan fasilitas untuk bebas memberikan pendapatnya dan pandangannya, (Pepper, 2009). Model PBL ini juga memberikan pengaruh positif bagi siswa agar lebih minat dalam belajar, (Dolmand and Schmidt 2006). Pembelajaran model PBL didesain oleh guru untuk memberikan sebuah permasalahan yang nyata agar lebih memahami dalam pelaksanaannya. Adanya permasalahan yang diberikan dapat membuat siswa berpikir kritis memecahkan masalah. Riset lain juga memaparkan bahwa pembelajaran berbasis masalah memberikan dampak dalam meningkatkan hasil belajar siswa, (Gonen and Basaran, 2008).

Model pembelajaran yang diterapkan oleh calon guru SD/MI sebaiknya pembelajaran yang aktif dan menyenangkan. Harapan tersebut harus sesuai dengan lulusan calon guru SD/MI yang profesional. Dapat 
510 Penerapan Pembelajaran Daring Menggunakan Model Problem Based Learning pada Mata Kuliah Konsep Biologi - Ragil Dian Purnama Putri, Siti Fatonah, Susilawati

DOI: https://doi.org/10.31004/edukatif.v4i1.1805

diketahui bahwa proses pembelajaran yang diterapkan oleh guru SD sekarang ini hanya monoton. Monoton yang dimaksud yaitu hanya sekedar untuk mengejar target kurikulum yang ada sehigga siswa tidak berperan secara aktif. Pembelajaran inilah yang mengakibatkan penguasaan dan hasil belajar siswa tidak sesuai dengan harapan, (Arends, 2008). Penguasaan konsep adalah salah satu unsur yang harus dipenuhi karena dapat menentukan berhasil tidaknya suatu keberhasilan pembelajaran. Adanya penguasaan konsep dapat menjelaskan konsep dan cara berfikir kritis siswa (Arends, 2008). Di dalam pembelajaran berpikir kritis akan membentuk sebuah konsep yang induktif. Dengan demikian, siswa sendiri yang akan menemukan suatu konsep dan mencapai konsep tersebut. Ada faktor yang dapat mempengaruhi penguasaan dari konsep siswa yaitu model pembelajaran yang diterapkan. Dari pemaparan di atas telah mengandung implikasi bahwa pembelajaran daring pada prodi PGMI memerlukan model pembelajaran yang tepat terlebih pada mata kuliah Konsep Biologi. Dengan demikian, peneliti tertarik untuk mengulas lebih dalam terkait pembelajaran daring menggunakan model PBL pada mata kuliah Konsep Biologi prodi PGMI UIN SUSKA Riau.

\section{METODE PENELITIAN}

Pendekatan kualitatif dengan metode deskriptif dapat digunakan untuk melakukan penelitian pada pembelajaran blanded learning mata kuliah Konsep Biologi. Penelitian ini melihat fenomena nyata di lapangan yang dialami oleh subjek dalam penelitian dengan menuliskan menggunakan bahasa ilmiah, (Moleong 2017). Jenis penelitian pada pendekatan kualitatif dengan menggunakan rancangan Penelitian Tindakan. Penelitian Tindakan yaitu suatu proses menginvestigasi untuk menemukan dan memecahkan pembelajaran di kelas yang dilakukan secara bersiklus (Akbar 2010). Penelitian Tindakan dilakukan untuk meningkatkan kualitas pembelajaran yang akhirnya dapat meningkatkan hasil belajar terlebih dalam penguasaan konsep pada mahasiswa.

Sedangkan subjek penelitian meliputi dosen Konsep Biologi sebagai pengampu kelas, dan mahasiswa semester 1 program studi PGMI UIN SUSKA Riau tahun ajaran 2021/2022. Objek dari penelitian ini yaitu berupa semua yang bersangkutan dengan pembelajaran blanded learning mata kuliah Konsep Biologi.

Pengumpulan data dengan menggunakan beberapa teknik. Teknik dalam mengumpulkan data menggunakan observasi, wawancara, maupun dokumentasi, (Sugiyono 2016). Metode ini digunakan untuk mendeskripsikan dengan objektif fakta yang terjadi di PGMI UIN SUSKA Riau. Adapun caranya yaitu melakukan proses analisis menggunakan pengumpulan data di lapangan, reduksi, penyajian, dan menarik kesimpulan.

\section{HASIL DAN PEMBAHASAN PENELITIAN}

\section{Pra Penelitian}

\section{a. Observasi Awal}

Peneliti melakukan observasi di PGMI UIN SUSKA Riau melalui aplikasi Google Meet pada tanggal 13 Oktober 2021. Observasi ini bertujuan untuk mengetahui permasalahan awal yang terjadi dalam kegiatan perkuliahan mata kuliah Konsep Biologi. Dari hasil observasi, peneliti telah menemukan beberapa masalah diantaranya mahasiswa dalam pembelajaran IPA masih perlu adanya bimbingan dalam menyelesaikan tugas. Hal ini disebabkan karena pembelajaran IPA harus lebih banyak mencoba secara langsung (Rahayu, Mulyani, and Miswadi 2012).

\section{b. Pelaksanaan Tes Awal}

Pelaksanaan tes awal ini dilakukan untuk mengetahui sejauh mana kemampuan dari mahasiswa pada mata kuliah Konsep Biologi. Hasil test awal ini digunakan untuk mengertahui kelompok pada mahasiswa 
511 Penerapan Pembelajaran Daring Menggunakan Model Problem Based Learning pada Mata Kuliah Konsep Biologi - Ragil Dian Purnama Putri, Siti Fatonah, Susilawati

DOI: https://doi.org/10.31004/edukatif.v4i1.1805

berdasarkan tingkat kemampuan. Tes awal terdiri dari 5 soal uraian mengenai materi Metabolisme. Hasil tes awal ini terdapat 12 mahasiswa masuk ke dalam katogeri kemampuan tinggi,

\section{Siklus I}

\section{a. Perencanaan Tindakan}

Hal yang dapat dilakukan oleh peneliti dalam melakukan Tindakan siklus I antara lain, yaitu:

1) Penyusunan Rencana Pelaksanaan Pembelajaran (RPP) dengan materi metabolisme untuk pertemuan I, materi katabolisme pada pertemuan II-III, dan materi anabolisme untuk pertemuan IV dengan menggunakan model pembelajaran PBL.

2) Menyusun 3 macam lembar kerja mahasiswa (LKM) sesuai materi yang dibahasa yaitu LKM dengan materi metabolisme, anabolisme, dan katabolisme.

3) Menyiapkan jurnal untuk belajar mahasiswa.

4) Menyusun soal tes untuk siklus I.

5) Menyusun lembar observasi kegiatan pembelajaran.

6) Membuat daftar kelompok mahasiswa berdasarkan nilai pre test terkait materi metabolisme, metabolisme, anabolisme, dan katabolisme.

Selain langkah-langkah yang harus disiapkan di atas, perlu adanya dokumentasi yaitu berupa gambar dan rekaman pelaksanaan pembelajaran.

\section{b. Pelaksanaan Tindakan}

Tindakan siklus I yaitu dilaksanakan 5 kali pertemuan. Adapun materi yang dibahas pada pertemuan I adalah Metabolisme. Sedangkan pertemuan II dan III membahas materi Anabolisme. Pada pertemuan ke IV membahas materi Katabolisme. Terakhir, pertemuan ke IV digunakan untuk Post Test siklus I. Setiap pertemuan dilaksanakan dalam 2 jam 30 menit pembelajaran daring.

\section{c. Data Hasil Observasi Siklus I}

Hasil observasi terhadap pelaksanaan pembelajaran daring telah terlaksana sesuai dengan tahapantahapan yang terdapat pada RPP. Berdasarkan dari pengamatan mahasiswa juga merespon pembelajaran dengan baik. Selain itu, kegiatan diskusi juga dilakukan antara mahasiswa dengan dosen berjalan dengan baik. Mahasiswa sangat antusias dalam pembelajaran daring dan aktif memberikan respon. Tetapi, ada juga beberapa mahasiswa yang masih pasif saat pembelajaran daring sehingga dalam kegiatan diskusi hanya diam dan menutup kamera. Selain itu, ada juga mahasiswa yang tidak fokus ketika dipanggil namanya hanya terdiam dan tidak mengaktifkan mikrofonnya.

Terdapat aktivitas peneliti yang belum terlaksana dengan sempurna seperti mereview kembali karena peneliti terbatas oleh waktu. Peneliti masih kurang dalam memberikan motivasi, sehingga belum mahasiswa antusias untuk melakukan kegiatan pembelajaran daring. Selain itu, ada mahasiswa yang kesulitan jaringan internet karena sering keluar masuk dari room meeting sehingga mahasiswa tidak dapat mengikuti pembelajaran secara keseluruhan.

\section{d. Data hasil Post Test Siklus I}

Hasil dari post test siklus I mendapatkan data bahwa mahasiswa mengalami kesalahan dalam menjawab beberapa soal metabolisme, anabolisme, dan katabolisme. Mahasiswa dalam menyampaikan pendapat atau menjawab pertanyaan ketika diskusi masih kurang sesuai dengan teori konsep IPA. 
512 Penerapan Pembelajaran Daring Menggunakan Model Problem Based Learning pada Mata Kuliah Konsep Biologi - Ragil Dian Purnama Putri, Siti Fatonah, Susilawati

DOI: https://doi.org/10.31004/edukatif.v4i1.1805

\section{e. Refleksi Siklus I}

Pada pelaksanaan pembelajaran siklus I pertemuan I peneliti menemukan beberapa hal yang dapat dibahas diantaranya yaitu:

1) Mahasiswa masih ada yang belum aktif saat proses pembelajaran, seperti tidak ada yang bertanya saat diskusi atau memberikan tanggapan. Mahasiswa belum siap dengan materi yang akan dipelajari karena masih ada yang belum membaca atau mencari referensi materi.

2) Hasil belajar pada siklus I masih perlu ditingkatkan lagi karena ada 12 mahasiswa hasil belajarnya belum mencapai KKM.

\section{Siklus II}

\section{a. Perencanaan Tindakan}

Hal yang dapat dilakukan oleh peneliti dalam melakukan tindakan siklus II antara lain, yaitu:

1) Penyusunan Rencana Pelaksanaan Pembelajaran (RPP) dengan materi metabolisme, katabolisme, dan anabolisme

2) Menyusun lembar kerja mahasiswa (LKM) sesuai materi yang dibahasa yaitu LKM dengan materi metabolisme, katabolisme, dan anabolisme.

3) Menyiapkan jurnal untuk belajar mahasiswa.

4) Menyusun soal tes untuk siklus II.

5) Menyusun lembar observasi kegiatan pembelajaran.

6) Membuat daftar kelompok mahasiswa berdasarkan nilai pretest terkait materi metabolisme, katabolisme, dan anabolisme.

Selain langkah-langkah yang harus disiapkan di atas, perlu adanya dokumentasi yaitu berupa gambar dan rekaman pelaksanaan pembelajaran.

\section{b. Pelaksanaan Tindakan}

Pada pelaksanaan siklus II dilakukan selam 2 kali pertemuan. Adapun materi yang dibahas pada pertemua I yaitu metabolisme. Selanjutnya pada pertemuan II yaitu digunakan untuk kegiatan posttest siklus II. Pertemuan ini dilaksanakan selama 2 jam 30 menit pembelajaran daring.

\section{c. Data Hasil Observasi Siklus II}

Pada hasil observasi ini pelaksanaan pembelajaran berjalan dengan baik sesuai dengan tahapan yang direncanakan dalam RPP. Mahasiswa dapat merespon dari dosen dan lebih aktif dari sebelumnya. Adapun mahasiswa ketika siklus I masih pasif, pada siklus II ini sudah mulai aktif menanggapi dan fokus mengikuti pembelajaran dengan membuka kamera. Selain itu, pembelajaran lebih kondusif karena pada siklus II mahasiswa sudah dapat mengikuti pembelajaran daring dengan antusias.

Berdasarkan hasil observasi juga ditemukan aktivitas peneliti yang belum terlaksana dengan sempurna untuk mereview materi secara keseluuruhan karena terbatas oleh waktu. Tetapi peneliti sudah memberikan motivasi penuh, sehingga mahasiswa sangat antusias untuk melakukan kegiatan pembelajaran daring menggunakan Google Meet. Selain itu, ada mahasiswa yang kesulitan jaringan internet karena sering keluar masuk dari room meeting sehingga mahasiswa tidak dapat mengikuti pembelajaran secara keseluruhan, (Putri, Nurhayati, and Dhori 2021).

Berdasarkan dari pengamatan terlihat secara keseluruhan aktivitas mahasiswa sudah lebih aktif dalam mengikuti pembelajaran. Mahasiswa sudah berkurang dalam mengeluh ketika diminta untuk mencari referensi tambahan pada materi yang akan dipelajarai. Suasana pembelajaran daring pada room meeting juga terlihat kondusif dan mahasiswa lebih fokus dengan membuka kamera. Selain itu, kegiatan diskusi yang dilakukan lebih efektif dan menantang untuk mahasiswa. 
513 Penerapan Pembelajaran Daring Menggunakan Model Problem Based Learning pada Mata Kuliah Konsep Biologi - Ragil Dian Purnama Putri, Siti Fatonah, Susilawati

DOI: https://doi.org/10.31004/edukatif.v4i1.1805

\section{d. Data hasil Post Test Siklus II}

Hasil post test pada siklus II telah diketahui bahwa mahasiswa sudah mengalami banyak peningkatan. Mahasiswa dalam mengerjakan soal mengalami peningkatan dan menanggapi pertanyaan teman dengan berdiskusi bersama sesuai dengan teori yang sesuai.

\section{e. Refleksi Siklus II}

Refleksi siklus II dapat disimpulkan bahwa kegiatan pada siklus II lebih baik dan mengalami peningkatan daripada pada siklus I. Mahasiswa dalam mengikuti proses pembelajaran berbasis problem based learning sangat antusias. Selain itu sudah banyak mahasiswa yang fokus dan aktif dengan menanggapi diskusi bersama.

\section{Penerapan Model Pembelajaran PBL dalam Meningkatkan Penguasaan mata Kuliah Konsep Biologi Mahasiswa PGMI UIN SUSKA Riau}

Pada pembelajaran mata kuliah Konsep Biologi SD/MI pada mahasiswa PGMI UIN SUSKA Riau yaitu dikembangkan dari: (1) tahapan model PBL, (2) diskusi bersama (3) LKM yang digunakan untuk mengetahui penguasaan konsep pada mata kuliaj Konsep Biologi terutama yaitu materi metabolisme, anabolisme, dan katabolisme. Adapun hasil pengamatan yang sudah dilakukan respon mahasiswa ketika diskusi dan menyelesaikan LKM sangat antusias. Dari persoalan yang terdapat pada lembar kerja saat berdiskusi terlihat bahwa PBL dapat meningkatkan penguasaan konsep (M. and Ibrohim 2016).

Sedangkan hasil dari observasi terlihat mahasiswa lebih tertantang ketika memahami materi dengan sebuah permasalahan yang diberikan. Dengan demikian, membuat mahasiswa lebih aktif ketika tanya jawab. Materi yang pelajari yaitu tentang metabolisme, anabolisme, dan katabolisme dapat diukur penguasaanya berdasarkan hasil tes pada sikuls I dan II. Berdasarkan tes awal mahasiswa masih banyak mengalami kesalahan dalam menyelesaikan soal metabolisme, anabolisme, dan katabolisme. Adapun hasil tes awal terdapat 25 mahasiswa masih memiliki skor di bawah KKM.

Dari hasil tes yang dilakukan telah mengalami peningkatan dari siklus I ke siklus II. Pada siklus I presentase mahasiswa mendapatkan skor di atas KKM sebanyak $75 \%$. Sedangkan pada siklus II presentase mahasiswa yang presentase mahasiswa yang mendapat skor di atas KKM meningkat menjadi $80 \%$. Kemudian presentase aktivitas diskusi pada siklus I sebesar $80 \%$, kemudian meningkat pada siklus II yaitu sebesar $90 \%$.

PBL dapat dikatakan salah satu model pembelajaran yang efektif di masa pandemi yaitu memberikan persoalan atau permasalahan kepada siswa dengan tujuan untuk memecahkan masalah, mencari informasi, dan menganaisis permasalahan tersebut (Assegaff and Sontani 2016). Dengan demikikian, PBL adalah metode instruksional yang dapat melatih siswa/ mahasiswa untuk belajar bekerjasama dalam kelompok dalam mencari solusinya, (Nugroho and Dwijanto 2013). Adapun pada pembelajaran model PBL di UIN SUSKA Riau ini sangat sesuai jika dilihat dari tahap siklus I dan siklus II. Hal tersebut karena pada dasarnya, pembelajaran IPA dengan berbasis masalah dapat meningkatkan keaktifan siswa/ mahasiswa dalam belajar, (Winanti 2009).

Dari penjelasan di atas dapat disimpulkan bahwa pada pembelajaran siklus I mahasiswa dengan tes awal masih banyak yang belum memenuhi skor KKM. Setelah dilakukan tindakan pada siklus II telah mengalami peningkatan. Dengan demikian hasil akhir siklus II telah meningkat dan memenuhi kriteria, sehingga tindakan telah diakhiri. Pada peningkatan ini menunjukkan bahwa model pembelajaran PBL dapat mempengaruhi efektivitas dalam melakukan penguasaan konsep mahasiswa. Pembelajaran pada mata kuliah Konsep Biologi dengan menggunakan metode PBL sangat mempengaruhi mahasiswa aktif dalam proses pembelajaran. 
514 Penerapan Pembelajaran Daring Menggunakan Model Problem Based Learning pada Mata Kuliah Konsep Biologi - Ragil Dian Purnama Putri, Siti Fatonah, Susilawati

DOI: https://doi.org/10.31004/edukatif.v4i1.1805

\section{KESIMPULAN}

Virus corona yang telah mengakibatkan seluruh tatanan kehidupan berubah. Perguruan tinggi yang menjadi tempat mahasiswa mencari ilmu harus melakukan pembelajaran secara daring. Prodi PGMI mempelajari berbagai ilmu termasuk Konsep Biologi. Dalam pembelajaran daring perlu adanya model pembelajaran yang tepat, yaitu Problem Based Learning (PBL). Adapun hasil yang didapatkan dalam penelitian ini yaitu pada siklus I pembelajaran daring menggunakan PBL belum efektif karena masih banyak mahasiswa yang tidak aktif dan salah dalam menjawab soal pertanyaan. Sedangkan, pada siklus II telah mengalami peningkatan, dimana mahasiswa terlihat aktif dalam menikuti diskusi dan sudah banyak yang tidak salah lagi dalam mengerjakan soal pertanyaan. Dengan demikian, dapat disimpulkan bahwa penerapan pembelajaran daring dengan model PBL sangat efektif bagi mahasiswa PGMI UIN SUSKA Riau.

\section{UCAPAN TERIMA KASIH}

1. Terima kasih kepada Prodi Pendidikan Guru madrasah Ibtidaiyah UIN SUSKA Riau yang telah membantu dan mendukung penelitian ini.

2. Terima kasih kepada program Pascasarjana Pendidikan Guru madrasah Ibtidaiyah UIN Sunan kalijaga yang telah mendukung adanya penelitian ini.

3. Terima kasih kepada seluruh informan yang turut membantu dalam memberikan informasi sedetail mungkin.

\section{DAFTAR PUSTAKA}

Akbar, Sa'dun. 2010. Penelitian Tindakan Kelas (Edisi Revisi). Yogyakarta: Cipta Media.

Arends, R. I. 2008. Learning To Teach (Belajar Untuk Mengajar). Yogyakarta: Pustaka Pelajar.

Assegaff, Asrani, And Uep Tatang Sontani. 2016. "Upaya Meningkatkan Kemampuan Berfikir Analitis Melalui Model Problem Based Learning (Plb) (Improved Ability To Analytical Thinking With A Problem Based Learning Model)." Jurnal Pendidikan Manajemen Perkantoran 1(1):38-48.

Brownell, J., And D. A. Jameson. 2004. "Problem-Based Learning In Graduate Management Education: An Integrative Model And Interdisciplinary Application.” Management Education 28(5):558-77.

Demirel, M., And B. A. Turan. 2010. "The Effect Of Problem Based Learning On Achievement, Attitude, Metacognitive Awareness And Motivation." Hacettepe Journal Of Education 38:55-66.

Dolmand, D. H. J. M., And Schmidt. 2006. "What Do We Know About Cognitive And Motivational Effects Of Small Group Tutorials In Problem- Based Learning?" Advances In Health Sciences Education 11(4):321-36.

Gonen, S., And B. Basaran. 2008. "The New Method Of Problem Solving In Physics Education By Using Scorm-Compliant Content Package." Turkish Online Journal Of Distance Education (Tojde) 9(3):11220.

Kemendikbud. N.D. "Surat Edaran Nomor 4 Tahun 2020 Tentang Pelaksanaan Program Belajar Dari Rumah (Bdr)."

M., Al Muhdhar M. H. Asyari, And H. S. Ibrohim. 2016. "Improving Critical Thinking Skills Through The Integration Of Problem Based Learning And Group Investigation." International Journal For Lesson And Learning Studies 5:36-44.

Moleong. 2017. Metode Penelitian Kualitatif. Bandung: Remaja Rosdakarya.

Nugroho, I. A. Chotim M., And Dwijanto. 2013. "Keefektifan Pendekatan Problem Based Learning Terhadap 
515 Penerapan Pembelajaran Daring Menggunakan Model Problem Based Learning pada Mata Kuliah Konsep Biologi - Ragil Dian Purnama Putri, Siti Fatonah, Susilawati

DOI: https://doi.org/10.31004/edukatif.v4i1.1805

Kemampuan Berpikir Kreatif Matematik.” Unnes Journal Mathematics Of Education 2(1):49-54.

Nurhayati, Tiara, Mohamad Agung Rokhimawan, And Ragil Dian Purnama Putri. 2021. "Pembelajaran Model Blanded Learning Pada Mata Kuliah Sains Lanjut Dengan Menggunakan Kurikulum Kkni." Jurnal Basicedu 5(5):3858-3865.

Pepper, C. 2009. "Problem Based Learning In Science.” Issues In Educational Research 19(2).

Putri, Ragil Dian Purnama, Tiara Nurhayati, And Muhammad Dhori. 2021. "Analisis Pemanfaatan Teknologi Informasi Dan Komunikasi Dalam Pembelajaran Di Sekolah Dasar Pada Masa Pandemi Covid-19." Jurnal Amal Pendidikan 2(1):31-38.

Putri, Ragil Dian Purnama, And Andi Prastowo. 2021. "Pengembangan Media Microsoft Power Point Sebagai Penunjang Pembelajaran Daring." Jurnal Amal Pendidikan 2(1):66-72.

Putri, Ragil Dian Purnama, And Suyadi. 2021. "Problematika Pembelajaran Daring Dalam Penerapan Kurikulum 2013 Tingkat Sekolah Dasar.” Jurnal Basicedu 5(5):3911-3920.

Rahayu, P., S. Mulyani, And S. S. Miswadi. 2012. "Pengembangan Pembelajaran Ipa Terpadu Dengan Menggunakan Model Pembelajaran Problem Base Melalui Lesson Study." Jurnal Pendidikan Ipa Indonesia 1(1):63-70.

Sadikin, Ali, And Afreni Hamidah. 2020. "Pembelajaran Daring Di Tengah Wabah Covid-19 (Online Learning In The Middle Of The Covid-19 Pandemic.” Biodik: Jurnal Ilmiah Pendidikan Biologi 6(2).

Safitri, Nindiya Eka, And Ragil Dian Purnama Putri. 2020. "Penguatan Pendidikan Karakter Di Masa Pandemi-Pasca Pandemi Covid-19: Kolaborasi Sekolah Dan Keluarga." In Seminar On Population, Family And Human Resources. Yogyakarta: Bkkbn Diy.

Setyadi, Sugeng, And Lili Indriyan. 2021. "Dampak Pandemi Covid-19 Terhadap Peningkatan Resiko Kemiskinan Di Indonesia." Pareto : Jurnal Ekonomi Dan Kebijakan Publik 4(1).

Sugiyono. 2016. Metode Penelitian Pendidikan Pendekatan Kuantitatif, Kualitatif, Dan $R$ \& D. Bandung: Alfabeta.

Winanti, S. 2009. "Pembelajaran Ipa Berbasis Masalahan Melalui Inkuiri Terbimbing Dan Inkuiri Bebas TerModifikasi Ditinjau Dari Sikap Ilmiah Dan Krati- Vitas Siswa." Program Studi Pendidikan Sains Program Pasca Sarjana Universitas Sebelas Maret. 